\title{
Low Thermal Pretreatment as Method for Increasing the Bioavailability of Organic Matters in Domestic Mixed Sludge
}

\author{
Roslinda Seswoya ${ }^{1, a}$ and Ahmad Tarmizi Abdul Karim ${ }^{1}$ \\ ${ }^{1}$ Faculty of Civil and Environmental Engineering, Universiti Tun Hussein Onn Malaysia, 86400 Parit Raja, Johor, \\ Malaysia
}

\begin{abstract}
In practice, primary and secondary sludge are fed into anaerobic digestion. However, the microbial cell exists in secondary sludge are an unfavorable substrate for biodegradation. Thermal pretreatment is proved to increase the bioavailability of organic and improve the biodegradation subsequently. During low thermal pretreatment, both intracellular (within the microbial cell) and extracellular (within the polymeric network) materials were extracted. This process increases the bioavailability meaning that organic compounds are accessible to the microorganisms for their degradation. This research aims to investigate the effect of thermal pretreatment on domestic mixed sludge disintegration. Domestic mixed sludge was thermally treated at $70^{\circ} \mathrm{C}$ for various holding times. The pre-thermally treated domestic mixed sludge was measured for protein and carbohydrates following the Lowry Method, and Phenol-Sulphuric Acid Method respectively. DR 6000 UV-Vis spectrophotometer, DRB200 Reactor (digester) and COD vial (TNT plus 822) were used for COD determination, based on Reactor Digestion Method approved by USEPA. The results showed that the organic matter in domestic mixed sludge is efficiently solubilised during thermal treatment organic matter. The higher soluble yield for each monitored parameter determined in this study indicated that low thermal pretreatment improve bioavailability.
\end{abstract}

\section{Introduction}

Sewage was treated using anaerobic digestion widely [1]. About 55\% to $70 \%$ methane rich biogas will be produced during the anaerobic digestion of sewage sludge, due to the presence of easily biodegradable organic in sewage sludge [2]. Typically, methane production potential from sewage sludge is approximately $300-400 \mathrm{~m}^{3} / \mathrm{VS}_{\text {added }}$ [3].

The pretreatment or sludge disintegration can be used to accelerate the solubilization of particulate organic matter in sewage. During pre-treatment, both intracellular (within the microbial cell) and extracellular (within the polymeric network) materials were extracted, increased the bioavailability subsequently. In comparison with other methods of pre-treatment, thermal pre-treatment has been considered to be a more promising technique due to less energy consumption and no chemical addition. More recently, the low and mild thermal pretreatment, has been gaining more attention because of similar efficiency compared with the conventional thermal pretreatment, which operated at high temperature [4 - 9]. The low and mild thermal pretreatment is operated at temperature less than

\footnotetext{
${ }^{\mathrm{a}}$ Corresponding author : roslinda@uthm.edu.my
} 
$120^{\circ} \mathrm{C}[6]$. The low thermal pretreatment $\left(70^{\circ} \mathrm{C}\right)$ showed positive effects on bioavailability of organic matter from municipal sewage sludge $[10,11]$. This paper seeks to evaluate the effect of the low thermal treatment of domestic sewage sludge disintegration. The influence of treatment time and treatment temperature is determined through variation of both parameters. In addition, the types of organic matters that are solubilized during the low thermal pretreatment are also discussed.

\section{Material and Methods}

\subsection{Sludge sampling}

For the experiments, sludge samples were taken from the full scale sewage treatment plant (STP) in Malaysia. The conventional wastewater treatment used in this plant consists of preliminary, primary treatment and secondary treatment. Activated sludge is a process applied in the secondary treatment. The sample is a mixture of primary and secondary sludge. The sludge was stored at $4^{0} \mathrm{C}$ in the laboratory until use.

\subsection{Low temperature $(700 \mathrm{C})$ pre-treatment}

The low temperature pretreatment was carried out at $70^{\circ} \mathrm{C}$ in order to enhance thermal solubilization of particulate material. The effect of thermal pretreatments depends both on treatment temperature and time. Therefore, in this work the effect of pretreatment time were evaluated by identifying the samples characteristics at different pretreatment times $(20 \mathrm{~min}, 40 \mathrm{~min}$ and $60 \mathrm{~min})$ in order to study the combined effect. Two (2) numbers of $0.5 \mathrm{~L}$ duran bottles, each containing $0.2 \mathrm{~L}$ of domestic mixed sludge were submerged in a thermostatic bath at $70^{\circ} \mathrm{C}$ during $20 \mathrm{~min}, 40 \mathrm{~min}$, and $60 \mathrm{~min}$. The duran bottles were covered with household aluminium foil, to avoid evaporation. Firstly, the thermostatic water bath was heated at the desired temperature, and the duran bottles were immersed in the water bath only when the temperature has reached the desired temperature. The thermal treatment duration was defined as the elapsed time between the moment at which the sample was immersed in the thermostatic water bath and the moment at which the sample was removed from the thermostatic water bath. After treatment, the sample was placed on the table and cooled passively to room temperature and stored at $4^{0} \mathrm{C}$ until use.

\subsection{Analytical method}

The following components were analyzed before and after thermal treatment on both the sludge and the supernatant to identify total and soluble fractions: COD, carbohydrate, and protein. The supernatant samples were obtained after centrifugation at $10,000 \mathrm{rpm}$ for $10 \mathrm{~min}$ and subsequent filtration through $0.45 \mu \mathrm{m}$ cellulose acetate filter [12]. The analysis performed on the supernatant will be called 'soluble', and the analysis on the sludge will be called 'total'. DR $6000 \mathrm{UV}$-Vis spectrophotometer, DRB200 Reactor (digester) and COD vial (TNT plus 822) were used for total and soluble COD determination, based on Reactor Digestion Method which was approved by USEPA. The protein and carbohydrate determination were conducted according to the Lowry Method [13] and Phenol-Sulphuric Acid Method [14] respectively. Bovine Serum Albumin (BSA) and glucose stock solutions were used as the protein and carbohydrate standards respectively. According to [10] the degree of solubilisation (\%) of the organic components is calculated by the following equation:

$$
\text { degree of solubilisation }(\%)=\frac{\mathrm{sC} \text { treated }-\mathrm{sC} \text { untreated }}{\mathrm{tC} \text { untreated }}
$$

where: $\mathrm{sC}$ treated $=$ soluble concentration treated, $\mathrm{sC}$ untreated $=$ soluble concentration untreated, and $\mathrm{tC}$ untreated $=$ total concentration untreated. 


\section{Results and Discussion}

\subsection{Effects of thermal treatment on the sludge solubilisation}

Thermal treatment on the domestic mixed sludge was performed at $70^{\circ} \mathrm{C}$ for three different treatment durations. An overview of the results is shown in Table 1. From the table, it is clear that a thermal treatment $\left(70^{\circ} \mathrm{C}\right)$ effectively releases the studied components (COD, protein, and carbohydrate) to the water phase, as the degree of solubilisation (\%) is higher at any treatment time. This means that the bioavailability of low thermally treated domestic mixed sludge is improved consequently. This finding is similar with the result obtained by [15], indicating that the sludge disintegration improves COD bioavailability. However, in this study the ultrasonic (low frequency of $31 \mathrm{kHz}$ ) was used for sludge disintegration and the municipal sewage sludge was studied instead of domestic sewage sludge.

Table 1. Concentration and degradation of the organic components of the untreated (raw) and pre-thermally treated domestic mixed sludge.

\begin{tabular}{|c|c|c|c|c|}
\hline \multirow{2}{*}{ Parameter } & \multirow{2}{*}{ Blank (Raw) } & \multicolumn{3}{|c|}{$7^{\circ} \mathrm{C}$} \\
\hline & & $20 \mathrm{~min}$ & $40 \mathrm{~min}$ & $60 \mathrm{~min}$ \\
\hline $\begin{array}{l}\text { COD total, TCOD } \\
(\mathrm{g} / \mathrm{L})\end{array}$ & $16.83 \pm 0.25$ & $8.05 \pm 0.07$ & $20.85 \pm 0.92$ & $21.45 \pm 0.21$ \\
\hline COD soluble, $\operatorname{SCOD}(\mathrm{g} / \mathrm{L})$ & $2.55 \pm 0.02$ & $3.19 \pm 0.01$ & $3.43 \pm 0.01$ & $3.54 \pm 0.02$ \\
\hline Solubilisation \% & 0.00 & 3.80 & 5.23 & 5.88 \\
\hline $\begin{array}{l}\text { Protein total } \\
(\mathrm{mgBSA}-\mathrm{eq} / \mathrm{L})\end{array}$ & $\begin{array}{c}3568.50 \pm \\
27.78\end{array}$ & $\begin{array}{c}6634.00 \pm \\
33.81\end{array}$ & $\begin{array}{c}8249.67 \pm \\
19.69\end{array}$ & $\begin{array}{c}7934.17 \pm \\
15.67\end{array}$ \\
\hline $\begin{array}{l}\text { Protein soluble } \\
(\mathrm{mg} \text { BSA -eq/L) }\end{array}$ & $47.9 \pm 0.89$ & $110.97 \pm 5.35$ & $163.37 \pm 2.30$ & $\begin{array}{c}176.83 \pm \\
1.04 \\
\end{array}$ \\
\hline Solubilisation \% & 0.00 & 1.77 & 3.24 & 3.61 \\
\hline $\begin{array}{l}\text { Carbohydrate total } \\
(\mathrm{mg} \text { Glu- eq /L) }\end{array}$ & $\begin{array}{c}1279.83 \pm \\
3.06\end{array}$ & $\begin{array}{c}2461.83 \pm \\
8.39\end{array}$ & $\begin{array}{c}4787.33 \pm \\
23.14\end{array}$ & $\begin{array}{c}5314.17 \pm \\
35.65\end{array}$ \\
\hline $\begin{array}{l}\text { Carbohydrate solubl } \\
\text { e(mg Glu-eq/L) }\end{array}$ & $52.77 \pm 0.31$ & $139.73 \pm 1.08$ & $169.73 \pm 0.75$ & $\begin{array}{c}202.63 \pm \\
2.48\end{array}$ \\
\hline Solubilisation \% & 0.00 & 6.79 & 9.14 & 11.79 \\
\hline
\end{tabular}

Note :

1) $16.83 \pm 0.25=$ average \pm stdev,

2) Triplicate sample were prepared for all measurement except duplicate sample for COD

3) Coefficient of variation (CV) for each data is less than $5 \%$

\subsection{Organic matter solubilisation}

Table 2 shows the ratio of SCOD/TCOD of untreated domestic mixed sludge and pre-thermally treated domestic mixed sludge at $70^{\circ} \mathrm{C}$. The value for ratio of SCOD/TCOD is higher at each treatment time. However, that treatment time of $20 \mathrm{~min}$ increased the ratio of SCOD/TCOD to almost 3 times higher than the SCOD/TCOD value of untreated domestic mixed sludge. It seems that 20 min treatment time is able to release the particulate COD into the water phase.

Treatment time at $40 \mathrm{~min}$ shows the biggest solubilisation, and no significant solubilisation increment observed at treatment time of $60 \mathrm{~min}$. There is a significant difference of COD solubilisation at $70^{\circ} \mathrm{C}$ of $60 \mathrm{~min}$ for both pre-thermally treated domestic sewage sludge and municipal sewage sludge. As for pre-thermally treated municipal sewage sludge, the COD solubilisation at 60 min is almost 3 times higher than the untreated sample [10]. On the contrary, the degree of solubilisation (in term of COD at $70^{\circ} \mathrm{C}$ of $60 \mathrm{~min}$ ) for pre-thermally treated domestic sludge is four times higher than pre-thermally treated municipal sewage sludge $(1.36 \%)$. This showed that that the 
low thermal pretreatment have a great potential for improving the bioavailability of domestic mixed sludge.

Table 2. The changes of SCOD/TCOD ratio at different treatment time (700C).

\begin{tabular}{|c|c|c|c|c|}
\hline \multirow{2}{*}{ Parameters } & \multirow{2}{*}{ Blank ( raw) } & \multicolumn{3}{|c|}{$\mathbf{7 0}^{\mathbf{0}} \mathbf{C}$} \\
\cline { 3 - 5 } & & $\mathbf{2 0 ~}$ min & $\mathbf{4 0}$ min & $\mathbf{6 0}$ min \\
\hline COD total, TCOD $(\mathrm{g} / \mathrm{L})$ & $16.83 \pm 0.25$ & $8.05 \pm 0.07$ & $20.85 \pm 0.92$ & $21.45 \pm 0.21$ \\
\hline COD soluble,SCOD $(\mathrm{g} / \mathrm{L})$ & $2.55 \pm 0.02$ & $3.19 \pm 0.01$ & $3.43 \pm 0.01$ & $3.54 \pm 0.02$ \\
\hline SCOD/TCOD $(\%)$ & 15.1 & 39.6 & 16.5 & 16.5 \\
\hline
\end{tabular}

\subsection{Carbohydrate and protein solubilisation}

Carbohydrates and proteins were solubilised due to thermal treatment at $70^{\circ} \mathrm{C}$. It was observed that the carbohydrate soluble and protein soluble concentration increased gradually with treatment time, indicating that more and more particulate organic matters in domestic mixed sludge become the soluble ones with the increase of treatment time. The soluble protein and carbohydrate is almost similar at treatment time $40 \mathrm{~min}$. While, at treatment time of $20 \mathrm{~min}$ and $60 \mathrm{~min}$ the carbohydrate is soluble more than protein. There are no significant changes of solubilisation (\%) for protein at $40 \mathrm{~min}$ and 60 min treatment time. On the other hand, the higher solubilisation (\%) observed for carbohydrate at higher treatment time. Referring to Table 1, the degree of solubilisation of carbohydrate is always higher compared to protein at any treatment time. This showed that carbohydrate in domestic mixed sludge was more soluble than protein when it was treated at $70^{\circ} \mathrm{C}$. This result contradicted with the findings from thermal pretreatment at $70^{\circ} \mathrm{C}$ for municipal sewage sludge as observed by [10], where carbohydrate was less soluble. The carbohydrate was also less soluble from the municipal sewage sludge with low organic content (VS/TS $=40 \%$ ) after undergoing pretreatment at $70^{\circ} \mathrm{C}[6]$. The percentage solubilisation (\%) observed from this study (domestic sewage sludge) for both carbohydrate and protein are higher than what was observed when municipal sewage sludge was used as shown by [10]. At the applied temperatures, a reaction of soluble carbohydrates with themselves or soluble proteins (forming e.g. Amadori compounds or melanoidins) was not expected in this study since the applied temperature is low. This hypothesis was confirmed visually because the sludge supernatant remained transparent and did not turn brown to a large extent after treatment.

\section{Conclusion}

The present paper studied the application of low temperature thermal treatment $\left(70^{\circ} \mathrm{C}\right)$ for domestic mixed sewage sludge disintegration. It was seen that organic compounds are efficiently solubilised during thermal treatment as indicated that higher organic release ina longer treatment time.This proved that sludge disintegration is able to improve the bioavailability of organic matter. This would promote the use of thermal pretreatment to enhance the anaerobic digestion of domestic mixed sewage sludge especially for efficient methane recovery. Future research will focus on the methane production from the pre-thermally treated domestic mixed sludge at various low temperature $\left(<100^{\circ} \mathrm{C}\right)$.

\section{Acknowledgement}

The authors would like to thank Universiti Tun Hussein Onn Malaysia (UTHM) for their financial support to make these research possible. The authors also would like to thank Unit Inovasi, IWK for the technical support. 


\section{References}

[1] A.F. Morgan-Sagastume, S. Pratt, A. Karlsson, D. Cirne, P. Lant and A. Werker, Production of volatile fatty acids by fermentation of waste activated sludge pre-treated in full-scale thermal hydrolysis plants, Bioresour. Technol., 102,3089-97, (2011).

[2] L. Appels, J. Baeyens, J. Degrève, and R. Dewil, Principles and potential of the anaerobic digestion of waste-activated sludge, Prog. Energy Combustion Science, 34(6), 755-781, (2008).

[3] Å. Davidsson, C. Lövstedt, J. Ia Cour Jansen, C. Gruvberger and H. Aspegren, Co-digestion of grease trap sludge and sewage sludge, Waste Manag., 28(6), 986-992, (2008).

[4] L. Appels, J. Lauwers, J. Degrève, L. Helsen, B. Lievens, K. Willems, J. Van Impe and R. Dewil, Anaerobic digestion in global bio-energy production: Potential and research challenges, Renew Sustainable Energy, 15(9), 4295-4301, (2011).

[5] W.J. Park and J.H. Ahn, Effects of microwave pretreatment on mesophilic anaerobic digestion for mixture of primary and secondary sludges compared with thermal pretreatment, Environ. Eng. Res., 16(2), 103-109, (2011).

[6] Y. Yan, H. Chen, W. Xu, Q. He and Q. Zhou, Enhancement of biochemical methane potential from excess sludge with low organic content by mild thermal pretreatment, Biochemical Engineering J., 70, 127-134, (2013).

[7] D. Bolzonella, P. Pavan, P. Battistoni and F. Cecchi, Mesophilic anaerobic digestion of waste activated sludge: influence of the solid retention time in the wastewater treatment process, Process Biochemical, 40, 1453-1460, (2005).

[8] M. Kuglarz, D. Karakashev and I. Angelidaki, Microwave and thermal pretreatment as methods for increasing the biogas potential of secondary sludge from municipal wastewater treatment plants, Bioresource Technologies, 134, 290-297, (2013).

[9] I.A. Nges and J. Liu, Effects of anaerobic pre-treatment on the degradation of dewatered-sewage sludge, Renewable Energy, 34(7), 1795-1800, (2009).

[10]L. Appels, J. Degrève, B. Van der Bruggen, J. Van Impe and R. Dewil, Influence of low temperature thermal pre-treatment on sludge solubilisation, heavy metal release and anaerobic digestion, Bioresource Technolgy, 101(15), 5743-5748, (2010).

[11]I. Ferrer, S. Ponsá, F. Vázquez and X. Font, Increasing biogas production by thermal $\left(70^{\circ} \mathrm{C}\right)$ sludge pre-treatment prior to thermophilic anaerobic digestion, Biochemical Engineering Journal, 42(2), 186-192, (2008).

[12]H. Yi, Y. Han and Y. Zhuo, Effect of combined pretreatment of waste activated sludge for anaerobic digestion process, Procedia Environmental Science, 18, 716-721, (2013).

[13] O.H. Lowry, N.J. Rosebrough, A.L. Farr, R.J. Randall and A. Lewis, Protein measurement with the folin phenol reagent, J. of Biological Chemistry, 193, 265-275, (1951).

[14] M. Dubois, K.A. Gilles, J.K. Hamilton, P.A. Rebers and F. Smith, Colorimetric method for determination of sugars and related substances, American Chemical Society, 28(3), 350-356, (1956).

[15]U. Neis, K. Nickel, and A. Tiehm, Enhancement of anaerobic sludge digestion by ultrasonic disintegration, Water Science Technologies, 42(9), 73-80, (2000). 